\title{
Economic Geology of the XIV Iron-Oxide Prospect, Bafq Mining District, Central Iran: A Preliminary Approach
}

\author{
Samira Bakhtiyari ${ }^{1}$, Mohammad Lotfi $^{2 *}$, Nima Nezafati ${ }^{1}$, Arash Gourabjeripour $^{3}$ \\ ${ }^{1}$ Department of Geology, Science and Research Branch, Islamic Azad University, Tehran, Iran \\ ${ }^{2}$ Department of Geology, North Tehran Branch, Islamic Azad University, Tehran, Iran \\ ${ }^{3}$ Faculty of Natural Resources, Myianeh Branch, Islamic Azad University, Miyaneh, Iran \\ Email: ${ }^{\star}$ M_lotfi_1014@yahoo.com
}

How to cite this paper: Bakhtiyari, S., Lotfi, M., Nezafati, N. and Gourabjeripour, A. (2016) Economic Geology of the XIV Iron-Oxide Prospect, Bafq Mining District, Central Iran: A Preliminary Approach. Open Journal of Geology, 6, 1580-1590. http://dx.doi.org/10.4236/ojg.2016.612112

Received: November 7, 2016 Accepted: December 25, 2016

Published: December 28, 2016

Copyright () 2016 by authors and Scientific Research Publishing Inc. This work is licensed under the Creative Commons Attribution International License (CC BY 4.0). http://creativecommons.org/licenses/by/4.0/

\begin{abstract}
This paper presents an overview about the XIV iron-oxide prospect which is located in the Bafq mining district, central Iran. The prospect and its host rocks were investigated by field observations together with mineralogical and geochemical studies. According to these investigations, the XIV prospect is similar to Kiruna-type iron deposits and demonstrates a magmatic source for the ore forming processes with a metasomatic overprinting.
\end{abstract}

\section{Keywords}

Magnetite, Metasomatism, Magmatic Iron, Kiruna, Central Iran

\section{Introduction}

The XIV (or No.14) iron-oxide prospect (geographic coordinates: $55^{\circ} 28^{\prime} \mathrm{E}-55^{\circ} 30^{\prime} \mathrm{E}$ and $32^{\circ} 04^{\prime} \mathrm{N}-32^{\circ} 07^{\prime} \mathrm{N}$ ) is located $8 \mathrm{~km}$ north of Chah Gaz magnetite deposit (also called as anomaly XIVA) and $60 \mathrm{~km}$ north of Bafq city (Figure $1 \&$ Figure 2). The prospect was first discovered and reported by Kumel in 1941. This prospect is divided into three ore zones (northern, central, and southern orebodies). According to the data obtained from drilling cores, the main orebody (northern zone) is continued down to $300 \mathrm{~m}$ below the surface. The iron content of the phosphorus-poor magnetite ore is $62 \%$. The northern ore zone mainly occurs in an aplite dome (caused by late differentiation of granite which is called "leuco-metasomatite") and is composed of the massive magnetite and hematite ore bodies, and actinolite, all of which located in the northern and southern parts of the area. The origin of the Bafq district deposits is the subject of longstanding 
debates and remains controversial. In this regard, the XIV iron-oxide prospect and its characteristics have so far received little attention. This paper presents the outcomes of the preliminary economic geological research on this prospect.

\section{Geologic Setting}

The XIV iron-oxide prospect is located in the Bafq district, which as part of the Central Iranian Micro-plate (CIM), composes the central part of the Alpine-Himalayan orogenic system. A series of intersecting regional-scale faults have divided the Central Iranian terrane into three major crustal domains, namely the Lut, Tabas, and Yazd blocks, among which lies an arc-shaped and structurally complex belt with more than $1000 \mathrm{~km}$

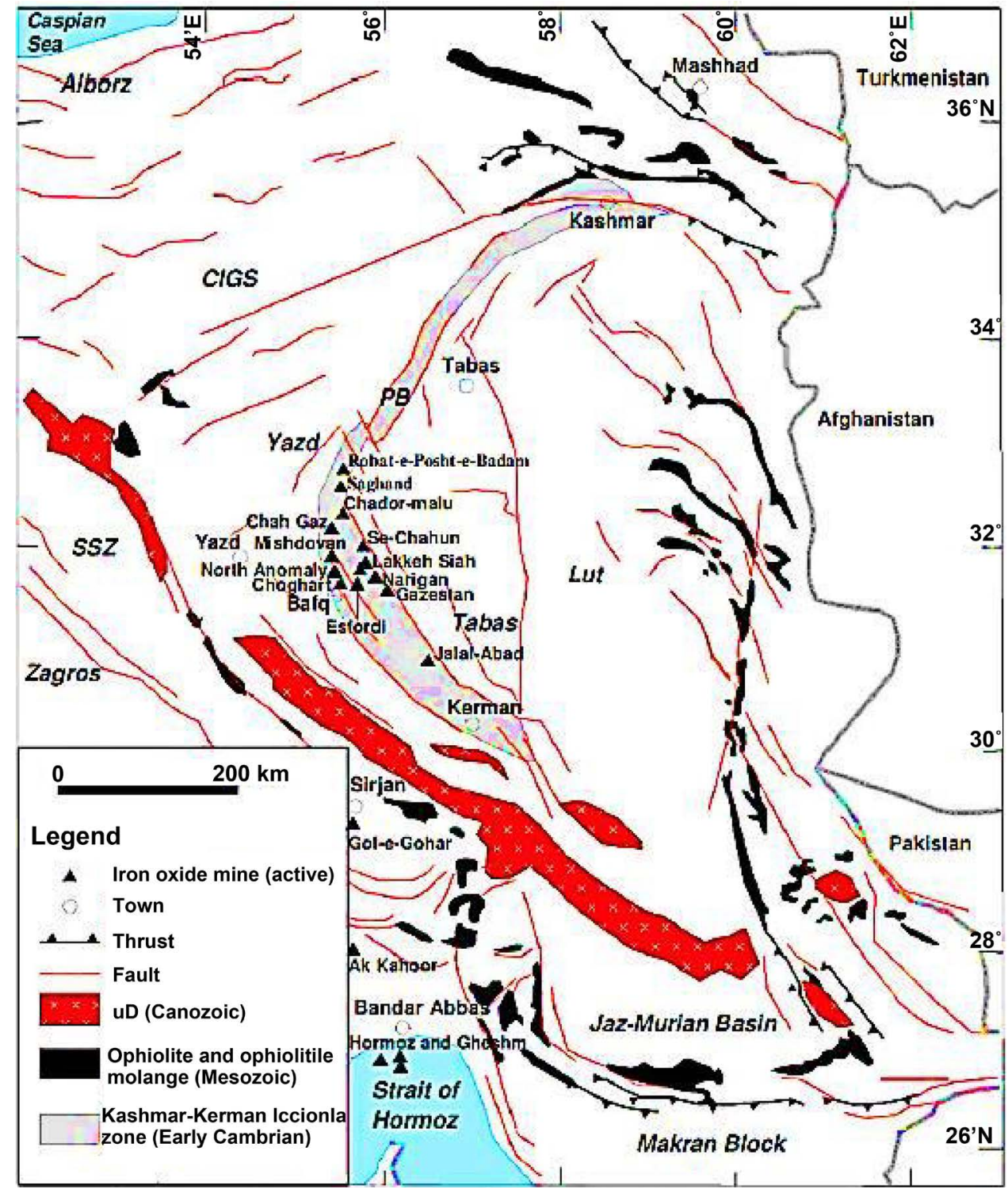

Figure 1. Structural map of CIM (including the Yazd, Posht-e-Badam block (PB) as well as Tabas, and Lut blocks) and CIZ (Central Iranian zone) ([1]-[7]) and location of major iron oxideapatite deposits in the Kashmar-Kerman tectonic zone (KKTZ). 
length and up to $80 \mathrm{~km}$ width. This belt is called the Kashmar-Kerman volcanoplutonic arc [1] [2] and hosts the Bafq district and the early Cambrian volcanic and plutonic rocks of Central Iran (Figure $1 \&$ Figure 2).

The local geologic setting and structure of the XIV iron prospect is presented in Figure 1 and Figure 2. It is based on both surface mapping and examination of shallow

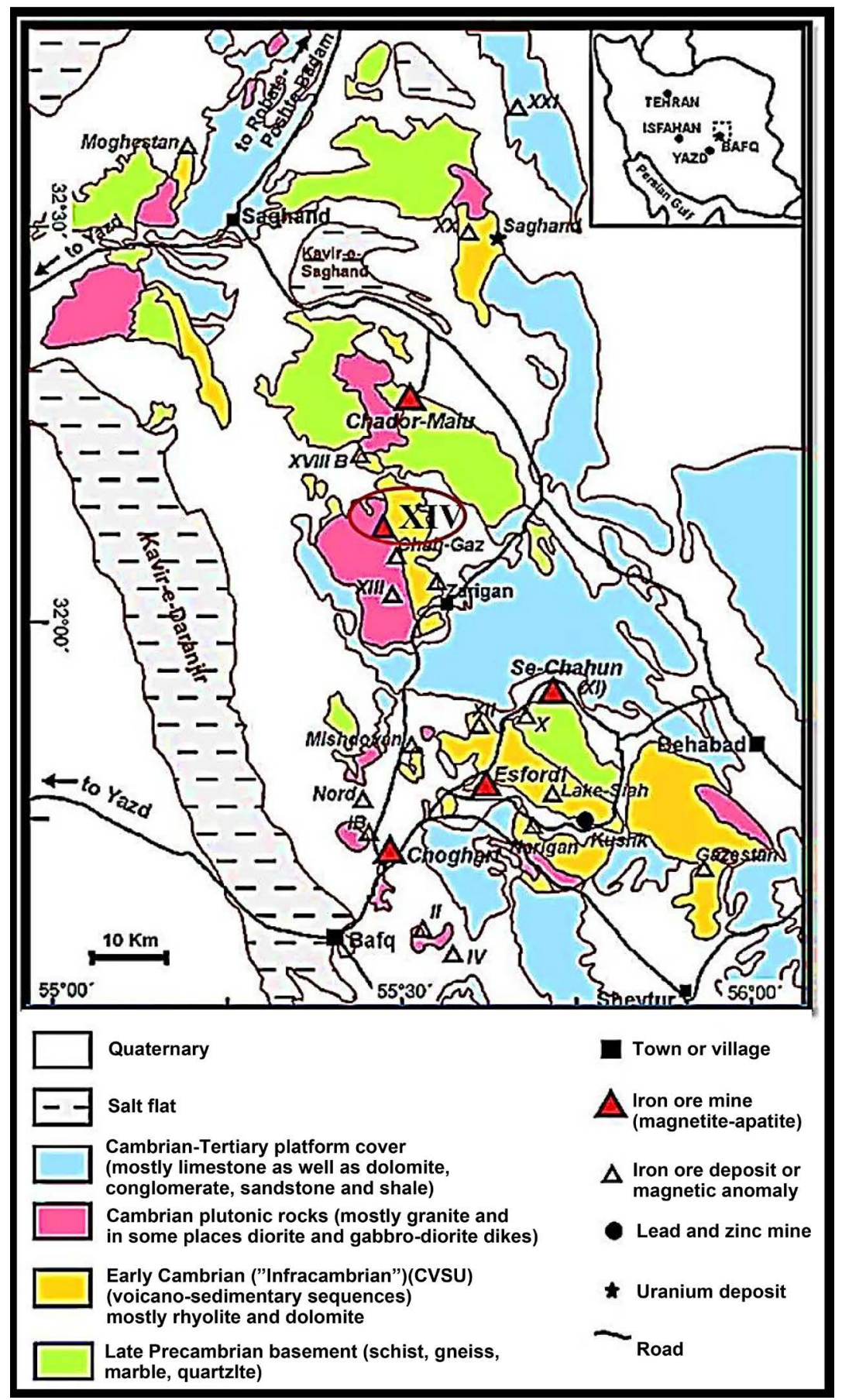

Figure 2. Simplified geological map of the Bafq mining district and location of ore deposits and igneous rocks ([6] [7] [8] [9]). 
exploratory core drilling from the vicinity of the deposit. The mineralization is hosted by the middle sequence of felsic to mafic volcanic and plutonic rocks (locally intruded by aplite and dolerite) and intercalated sedimentary rocks of the Esfordi formation [3]. The main host rock of the diatreme is aplite (the result of late differentiation of granite which is called "leuco-metasomatite").

An aplite dome with approximate dimensions of $100 \mathrm{~m} \times 400 \mathrm{~m}$, is situated around the mineralization (in northern zone, Figure 3(a) \& Figure 3(b)) and has a sharp contact with the ore body. A small outcrop of cherty dolomites of Esfordi formation was found on the southern margin of the XIV iron prospect. Massive granite-gabbro diorite outcrops have been exposed in the south, central, and north-eastern parts of the XIV prospect, while the metamorphic rocks are present in the south of the area in the contact of gabbro and granitic rocks (Figure 5(a) \& Figure 5(b)).

The intrusive rocks and the iron ores have been regionally metamorphosed with preservation of their primary structures and textures. Presence of minerals like chlorite, epidote, actinolite, and albite in the mafic rocks indicates the occurrence of a green schist facies. According to the field observations, the ore body is associated with an extensive fault zone. Local deformation and recrystallization are caused by reactivation of the fault system. Quartz and carbonates were probably introduced during the deformation. This also has caused the formation of foliated regions in the ore. The volcanic succession which contains the ore is approximately $6 \mathrm{~km}$ thick. The iron oxide mineralization is situated on the contact zone of a plutonic sequence composed of granitic and gabbro rocks (central part and south of the area) and the aplitic unit (north of area). The majority of these are altered and their chemistry has changed from alkali-rich to low-content alkaline series.

\section{Mineralization of the Ore Body}

Mineralization at the XIV iron prospect occurs predominantly within the actinoliterich metasomatic rocks, granitic, and aplitic rocks and gabbro. The northern (zone) ore body (Figure 3(a) \& Figure 3(b)), is characterized mainly by a massive mineralization style. This orebody shows sharp and linear contacts with the host rocks (Figure 3(a) \& Figure 3(b)).

The orebodies of the XIV prospect is mainly in massive, stockwork, and breccia forms. The XIV iron ore is dominantly composed of magnetite and hematite. The ore contains rare apatite (mainly fluorapatite) together with poor contents of actionolite, local biotite, calcite, quartz, sphene, talc, and albite.

The iron-oxide-rich breccias usually occur at the top of the massive ore. The breccias consist of angular fragments of the metasomatic host rock cemented by iron ore (Figure 4). Stockwork iron ore locally occurs as irregular cross-cutting network of veinlets of magnetite and hematite, which commonly cut the massive orebodies as well as the associated volcanic rocks. The veinlets vary in thickness, from a few millimeters to a few centimeters. Locally, the magnetite and/or hematite bodies contain feldspar and quartz phenocrysts, whose abundance decreases towards the center of the ore bodies. 

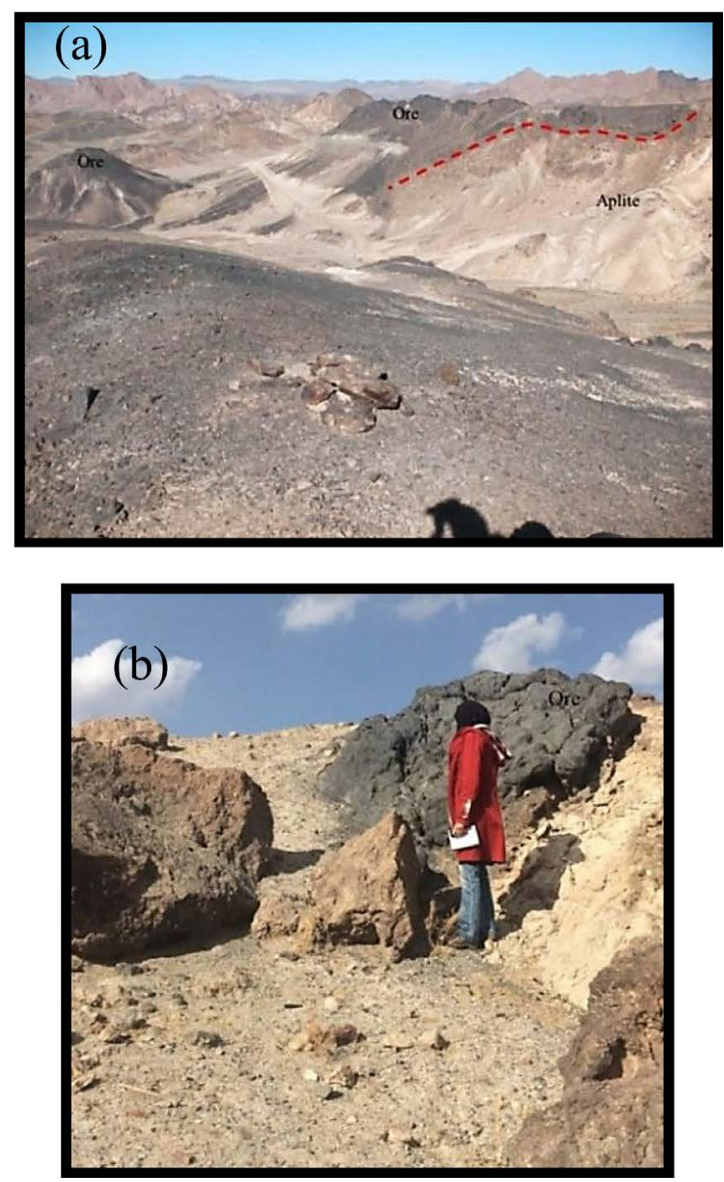

Figure 3. (a) The northern massive orebody in the XIV iron prospect. This orebody shows sharp and linear contacts with the host rocks, (b) the massive ore body in south of the study area.

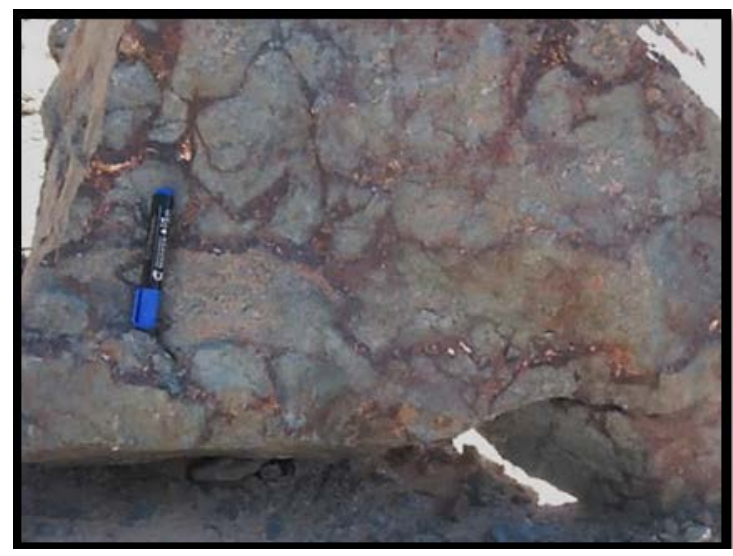

Figure 4. The breccias consist of angular fragments of the metasomatic host rocks cemented by iron ore.

Although disseminated magnetite and/or hematite are widespread around the ore in the volcanic and plutonic rocks, most of the abovementioned disseminated magnetite is commonly concentrated around the massive orebody. Most plutonic and volcanosedimentary host rocks are altered and the original chemistry of these rocks is strongly 
modified by sodic (and sodic-calcic), potassic, and calcic overprint.

Some fine-grained crystals of apatite are locally visible in thin section of rocks but are invisible in the massive magnetite bodies or in the ore-breccia zones.

Actinolite is the most important silicate mineral present in the iron deposit (Figure 5(a) \& Figure 5(b)). It occurs in the form of euhedral to subhedral grains and demonstrates a continuous series with tremolite, indicating variable degrees of iron metasomatism of the host rocks. In the XIV iron prospect, actinolite occurs in massive bodies (the so called green rock) adjacent to or interfingering with magnetite ore. A massive thick actinolite layer has been developed in the contact zone between the granitic rocks and gabbro (Figure 5(a) \& Figure 5(b)). Other hydrothermal minerals are quartz, calcite, albite, k-feldspar, sericite, chlorite, talc, sphene, and epidote.

Sulfides are rare. Only some pyrite and few fine-grained chalcopyrite crystals were observed in some drilling cores (Figure 6(a) \& Figure 6(b)). Goethite and other hydrous iron oxide minerals occur near the surface, but disappear rapidly towards deeper levels.

\section{The Alteration of the XIV Iron Prospect}

The alteration assemblages associated with the iron ore deposits are evidence of an important metasomatic component in the ore-forming process, where the alteration mineralogy is controlled by the bulk chemistry of rock, the composition of the mineralizing fluids, and P-T conditions of formation. However, alteration at the XIV iron prospect shows a general transition from sodic alteration (albite-rich) at deeper levels especially in the plutonic rocks or their adjacent volcanics, to potassic alteration (potassium feldspar + sericite) at intermediate levels (in the plutonic), to sericitic and silicic alteration (sericite + quartz) in the uppermost portion of the system. Actinolite (sodic-calcic
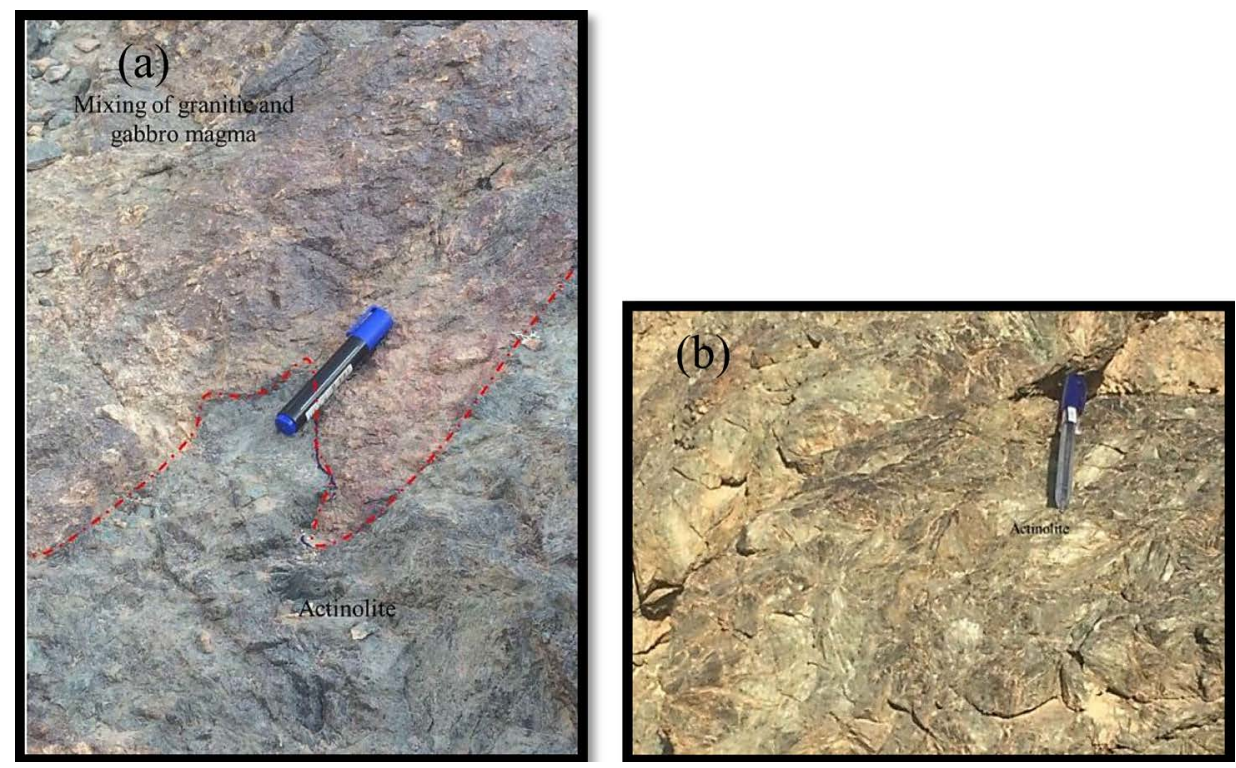

Figure 5. (a) A massive thick amphibole layer has been developed as the contact zone between the mixing of granitic rocks and gabbro, (b) massive actinolite grains. 

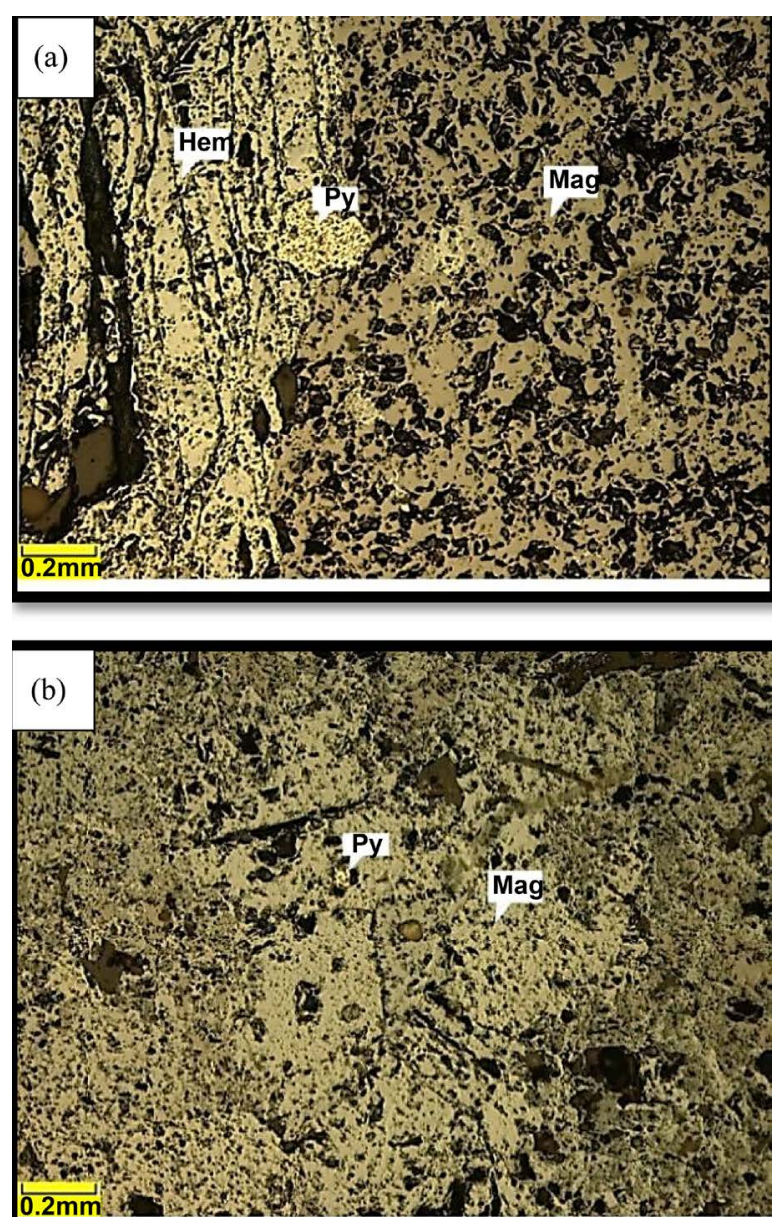

Figure 6. (a) and (b) General paragenesis of the iron minerals (Py: pyrite; Mag: magnetite; Hem: hematite).

alteration) also occurs widely in the southern and western parts of the area, locally associated with albite as $\mathrm{Na}-\mathrm{Ca}$ alteration at deeper levels, or as patches or massive bodies in contact zone between the gabbro and granitic rocks due to hydrothermal metasomatism.

\section{Discussion}

\subsection{The Age of the Ore}

The XIV iron ore is outcropped by aplite domes. Ramezani and Tucker [1] defined an age of $525 \pm 7 \mathrm{Ma}$ and $529 \pm 16 \mathrm{Ma}$ (U-Pb on zircon) for the Zarigan and the Chador-Malu granites, respectively. Stosch et al. [10] determined the U-Pb apatite age for major iron oxide apatite deposits in the Bafq district (527 - $539 \mathrm{Ma}$ ). These ages fell entirely within the age range of the felsic plutonic rocks of the Bafq district dated by Ramezani and Tucker [1] (525 - $547 \mathrm{Ma}$; U-Pb on zircon). The XIV iron ore is overlain in sharp contact by aplite domes which is probably younger and/or synchronic in age with the aplitic rocks. All results show that the XIV iron mineralization was completed before 507 - $542 \mathrm{Ma}$. 


\subsection{Genesis of the Mineralization}

The origin of the massive iron oxide deposits related to igneous rocks has been the subject of a long-standing and hot debate for the last hundred years. Among these deposits, the so-called Kiruna-type ores have attracted the most attention. Several genetic models have been proposed for this specific type of massive iron oxide deposits. Today researchers put forward two different genetic models involving magmatic [11]-[17] and hydrothermal processes [18]-[27].

The origin of the Bafq district deposits is the subject of longstanding debate and remains controversial. Different ore genesis models have been proposed for these ore deposits. Some researchers have proposed an IOCG affinity for the Bafq district deposits [6] [7] [11] [24], after the classification that was defined by Hitzman et al. [20]. Evidence for an IOCG association includes the presence of hydrothermal alteration with the characteristic zoning of the IOCG deposits (as defined by Hitzman et al. [20]) and magnetite chemistry [6].

Jami [4] developed a three-stage model for the hydrothermal evolution of the Esfordi deposit based on apatite textures, fluid inclusions, and isotopic data; however, the initial stages in the generation of the proto iron oxide-apatite body was largely speculative and involved the immiscible separation of a Fe-P melt (in response to a possible magma mixing in the Esfordi area) and its subsequent equilibration with fluids near $400^{\circ} \mathrm{C}$ [5]. Some researchers have proposed that the source of $\mathrm{Fe}$ is the pre-existing mafic minerals (iron-bearing amphibole and pyroxene) of the Precambrian rocks of the region which would decompose in the early stages of regional-scale hydrothermal fluid circulation to supply Fe to the system [25] [26] [28].

Based principally on the flow and quenching textures observed in magnetite, liquid magmatic models have been ascribed a prominent role at Kiruna and El Laco [9] [29]. This textural evidence was reported from the Bafq district deposits and interpreted as their direct magmatic origin by Förster and Jafarzadeh [10]. Magmatic models involving immiscibility between silicate and iron oxide-rich melts have widely been proposed for the genesis of Kiruna type deposits [12] [13] [30] [31] [32].

The Bafq district deposits, of which the XIV iron deposit is typical, are remarkably similar to the Kiruna-type iron oxide-apatite deposits. They consist of massive to brecciated and conformable lenses of magnetite-hematite, which are mainly hosted by felsic volcanic rocks, very similar to the classic Kiirunavaara deposit (northern Sweden), in terms of morphology, ore mineralogy and host lithology; the latter ranging in composition from felsic to intermediate for the Swedish counterpart [19]. The volcanic hosts of both districts (Bafq and Kiruna) have undergone intense alteration and formed similar assemblages including actinolite and albite [4] [6] [19] [33].

\section{Conclusions}

Based on the field relationships and ages reported for rocks of Bafq district, the XIV iron prospect has probably occurred before 507 - $542 \mathrm{Ma}$. The ore is surrounded by aplite. The deposit is composed of a concordant body of magnetite and/or hematite ore 
which contains circa 5\% apatite and some accessory minerals. Different alteration events from sodic (and sodic-calcic) to potassic, sericitic and silicic have occurred in the deposit.

The spatial association of the XIV iron prospect with intrusive and extrusive igneous rocks clearly indicates a genetic relationship between magmatism and iron-oxide ore formation. The field relationships and the overall geological evidence at the XIV iron occurrence indicate that the aplitic host rocks were roughly synchronous and coeval with mineralization. The magnetite-hematite ores of the XIV iron prospect were probably formed by magmatic differentiation and magma mixing of the gabbro and granitic magmas. Moreover, the Fe-melt has been derived from it by liquid immiscibility which separated from a silica-rich melt.

\section{Acknowledgements}

The present study is based on the first author's $\mathrm{PhD}$ thesis at Science and Research branch of the Islamic Azad University, Tehran, Iran. The authors would like to thank the editor and referees for their critiques and suggestions that helped to improve the quality of the paper. This work was supported by the Iran Minerals Production \& Supply Co. (IMPASCO) and IMIDRO. The authors express their gratitude to the managers of the ICIOC (Iranian Central Iron Ore Co.) and Chah Gaz mine for permission to access the deposit, sampling and support during the field work.

\section{References}

[1] Ramezani, J. and Tucker, R.D. (2003) The Saghand Region, Central Iran: U-Pb Geochronology, Petrogenesis and Implications for Gondwana Tectonics. American Journal of Science, 303, 622-665. https://doi.org/10.2475/ajs.303.7.622

[2] Nabatian, G.H., Rastad, E., Neubauer, F., Honarmand, M. and Ghaderi, M. (2015) Iron and Fe-Mn Mineralisation in Iran: Implications for Tethyan Metallogeny. Australian Journal of Earth Sciences. An International Geoscience Journal of the Geological Society of Australia, 62, 211-241. https://doi.org/10.1080/08120099.2015.1002001

[3] Samani, B. (1993) Saghand Formation, a Riftogenic Unit of Upper Precambrian in Central Iran. Geoscience Scientific Quarterly Journalof Geological Survay of Iran, 2, 32-45. (In Farsi with English Abstract)

[4] Jami, M. (2005) Geology, Geochemistry and Evolution of the Esfordi Phosphate-Iron Deposit, Bafq Area, Central Iran. Unpublished PhD Thesis, The University of New South Wales, Australia.

[5] Jami, M., Dunlop, A.C. and Cohen, D.R. (2007) Fluid Inclusion and Stable Isotope Study of the Esfordi Apatite-Magnetite Deposit, Central Iran. Economic Geology, 102, 1111-1128. https://doi.org/10.2113/gsecongeo.102.6.1111

[6] Torab, F. (2008) Geochemistry and Metallogeny of Magnetite-Apatite Deposits of the Bafq Mining District, Central Iran. Unpublished PhD Thesis, Clausthal University of Technology, Germany.

[7] Torab, F.M. and Lehmann, B. (2007) Magnetite-Apatite Deposits of the Bafq District, Central Iran: Apatite Geochemistry and Monazite Geochronology. Mineralogical Magazine, 71, 347-363. https://doi.org/10.1180/minmag.2007.071.3.347 
[8] Haghipour, A. (1977) Geological Map of the Biabanak-Bafq Area (Scale 1:500,000). Geological Survey of Iran.

[9] Henriquez, F. and Nyström, J.O. (1998) Magnetite Bombs at El Laco Volcano, Chile. GFF, 120, 269-271. https://doi.org/10.1080/11035899809453216

[10] Forster, H. and Jafarzadeh, A. (1994) The Bafq Mining District in Central Iran-A Highly Mineralized Infracambrian Volcanic Field. Economic Geology, 89, 1697-1721. https://doi.org/10.2113/gsecongeo.89.8.1697

[11] Stosch, H.G., Romer, R.L., Daliran, F. and Rhede, D. (2011) Uranium-Lead Ages Apatite from Iron Oxide Ores of the Bafq District, East-Central Iran. Mineralium Deposita, 46, 921. https://doi.org/10.1007/s00126-010-0309-4

[12] Frietsch, R. (1978) On the Magmatic Origin of Iron Ores of the Kiruna Type. Economic Geology, 73, 478-485. https://doi.org/10.2113/gsecongeo.73.4.478

[13] Frietsch, R. (1984) On the Magmatic Origin of Iron Ores of the Kiruna-Type: A Reply. Economic Geology, 79, 1949-1951. https://doi.org/10.2113/gsecongeo.79.8.1949

[14] Nystrom, J.O. and Henriquez, F. (1994) Magmatic Features of Iron Ores of the Kiruna Type in Chile and Sweden: Ore Textures and Magnetite Geochemistry. Economic Geology, 89, 820-839. https://doi.org/10.2113/gsecongeo.89.4.820

[15] Bergman, S., Kubler, L. and Martinsson, O. (2001) Description of Regional Geological and Geophysical Maps of Northern Norrbotten County (East of the Caledonian Orogen). Geological Survay of Sweden, 56, $110 \mathrm{p}$.

[16] Naslund, H.R., Henriquez, F., Nystroem, J.O., Vivallo, W. and Dobbs, F.M. (2002) Magmatic Iron Ores and Associated Mineralisation: Examples from the Chilean High Andes and Coastal Cordillera. In: Porter, T.M., Ed., Hydrothermal Iron Oxide Copper-Gold and Related Deposits. A Global Perspective, PGC Publishing, Adelaide, Vol. 2, 207-226.

[17] Jonsson, E., Troll, V.R., Hgdahl, K., Harris, C.H., Weis, F., Nilsson, K.P. and Skelton, A. (2013) Magmatic Origin of Giant "Kiruna-Type" Apatite-Iron-Oxide Ores in Central Sweden. Scientific Reports, 3, Article No. 1644. https://doi.org/10.1038/srep01644

[18] Cliff, R.A., Rickard, D. and Blake, K. (1990) Isotope Systematics of The Kiruna Magnetite Ores, Sweden; Part 1, Age of the Ore. Economic Geology, 85, 1770-1776. https://doi.org/10.2113/gsecongeo.85.8.1770

[19] Hitzman, M.W. (2000) Iron Oxide-Cu-Au Deposits: What, Where, When and Why. In: Porter, T.M., Ed., Hydrothermal Iron Oxide Copper-Gold and Related Deposits. A Global Perspective, PGC Publishing, Adelaide, Vol. 1, 9-25.

[20] Hitzman, M.W., Oreskes, N. and Einaudi, M.T. (1992) Geological Characteristics and Tectonic Setting of Proterozoic Iron Oxide (Cu-U-Au-REE) Deposits. Precambrian Research, 58, 241-287. https://doi.org/10.1016/0301-9268(92)90121-4

[21] Rhodes, A.L. and Oreskes, N. (1999) Geology and Rare Earth Element Geochemistry of Magnetite Deposits at El Laco, Chile. Special Publication-Society of Economic Geologists, 17, 299-332.

[22] Evans, A.M. (2000) Ore Geology and Industrial Minerals-An Introduction. Blackwell Science, Oxford.

[23] Barton, M.D. and Johnson, D.A. (1996) Evaporitic-Source Model for Igneous-Related Fe oxide-(REE-Cu-Au-U) Mineralization. Geology, 24, 259-262. https://doi.org/10.1130/0091-7613(1996)024<0259:ESMFIR>2.3.CO;2

[24] Daliran, F. (2002) Kiruna-Type Iron Oxide-Apatite Ores and Apatitites of the Bafq District, Iran, with an Emphasis on the REE Geochemistry of Their Apatites. In: Porter, T.M., Ed., Hydrothermal Iron Oxide Copper-Gold and Related Deposits. A Global Perspective, PGC 
Publishing, Adelaied, Vol. 1, 303-320.

[25] Daliran, F., Stosch, H.G. and Williams, P. (2007) Multistage Metasomatism and Mineralization at Hydrothermal Fe Oxide-REE-Apatite Deposits and Bapatitites of the Bafq District, Central-East Iran. Proceedings of the 9 th Biennial SGA Meeting "Mineral Exploration and Research: Digging Deeper”, Dublin, 20-23 August 2007, 1501-1504.

[26] Daliran, F., Stosch, H.G., Williams, P., Jamali, H. and Dorri, M.B. (2010) Early Cambrian Iron Oxide-Apatite-REE (U) Deposits of the Bafq District, East-Central Iran. In: Corriveau, L. and Mumin, H., Eds., Exploring for Iron Oxide Copper-Gold Deposits: Canada and Global Analogues, Geological Association of Canada, St. John's, 147-160.

[27] Smith, M.P., Gleeson, S.A. and Yardley, B.W.D. (2013) Hydrothermal Fluid Evolution and Metal Transport in the Kiruna District, Sweden: Contrasting Metal Behavior in Aqueous and Aqueous-Carbonic Brines. Geochimica et Cosmochimica Acta, 102, 89-112. https://doi.org/10.1016/j.gca.2012.10.015

[28] Haghipour, A. (1974) Étude géologique de la region de Biabanak-Bafq (Iran Central): Pétrographie et tectonique du scole Précambrien et de sa couverture. Unpublished $\mathrm{PhD}$ Thesis, Université de Grenoble, France.

[29] Foose, M.P. and McLelland, J.M. (1995) Proterozoic Low-Ti Iron-Oxide Deposits in New York and New Jersey: Relation to Fe-Oxide, $\mathrm{Cu}-\mathrm{U}-\mathrm{Au}$-Rare Earth Element, Deposits and Tectonic Implications. Geology, 23, 665-668. https://doi.org/10.1130/0091-7613(1995)023<0665:PLTIOD>2.3.CO;2

[30] Naslund, H.R., Aguirre, R., Dobbs, F.M., Henriquez, F.J. and Nystrom, J.O. (2000) The Origin, Emplacement, and Eruption of Oremagmas. IX Congreso Geologico Chileno Actas, 2, 135-139.

[31] Philpotts, A.R. (1967) Origin of Certain Iron-Titanium Oxide and Apatite Rocks. Economic Geology, 62, 303-315. https://doi.org/10.2113/gsecongeo.62.3.303

[32] Philpotts, A.R. (1982) Composition of Immiscible Liquids in Volcanic Rocks. Contributions to Mineralogy and Petrology, 80, 201-218. https://doi.org/10.1007/BF00371350

[33] Bonyadi, Z., Davidson, G.J., Mehrabi, B., Meffre, S. and Ghazban, F. (2011) Significance of Apatite REE Depletion and Monazite Inclusions in the Brecciated Se-Chahun Iron Oxide-Apatite Deposit, Bafq District, Iran: Insights from Paragenesis and Geochemistry. Chemical Geology, 281, 253-269. https://doi.org/10.1016/j.chemgeo.2010.12.013

\section{Submit or recommend next manuscript to SCIRP and we will provide best service for you:}

Accepting pre-submission inquiries through Email, Facebook, LinkedIn, Twitter, etc.

A wide selection of journals (inclusive of 9 subjects, more than 200 journals)

Providing 24-hour high-quality service

User-friendly online submission system

Fair and swift peer-review system

Efficient typesetting and proofreading procedure

Display of the result of downloads and visits, as well as the number of cited articles

Maximum dissemination of your research work

Submit your manuscript at: http://papersubmission.scirp.org/

Or contact ojg@scirp.org 